\title{
"LA MANO DEL PLEBEYO LEVANTADA, ES LA MONTAÑA QUE SE DESPEÑA". LA CONCEPTUALIZACIÓN DEL PUEBLO EN TIEMPOS DE TRANSFORMACIÓN. CHILE, 1750-1850
}

\begin{abstract}
A través de la aplicación de herramientas de análisis inspiradas en la historia conceptual, el siguiente artículo pretende dar cuenta de las continuidades y transformaciones semánticas que el concepto pueblo experimentó a lo largo del periodo comprendido por las últimas décadas del dominio colonial, las luchas de la Independencia, el establecimiento del régimen conservador y las asonadas liberales organizadas en su contra. A partir del análisis en lo fundamental de escritos políticos contingentes, se busca evidenciar el doble proceso conceptual que caracterizó la utilización del constructo pueblo por parte del pensamiento y la opinión política durante los cien años comprendidos en este estudio: por un lado la persistencia de una concepción amenazante de los sectores más desposeídos de la sociedad, tematizada bajo el binomio caridad/policía; y por otro, la elaboración de significados de cuño liberal e ilustrado, definidos por la función de legitimidad soberana y regeneración política que la ciudadanía popular debía representar.
\end{abstract}

Palabras clave: pueblo, historia conceptual, historia social, liberalismo.

Considering the use of analytical tools inspired in conceptual history, this article attempts to reveal semantic continuities and transformations of the concept "people" from the last decades of colonial rule to the protest demonstrations organized by liberals against the conservative regime by mid-nineteenth century. Based on the analysis of the fundamental aspects of contingent political texts, the article shows the double conceptual process that characterized the use of the word "people" by thinkers and public opinion during the one hundred years considered in this study. On one hand the persistence of a menacing notion of dispossessed population under the binomial relationship between charity/police. On the other the elaboration of liberal and enlightened meanings defined under notions of sovereign legitimacy and political regeneration that popular citizens had to represent

Key words: People, conceptual history, social history, liberalism.

Fecha de recepción: mayo 2008

Fecha de aceptación: marzo 2009

* Universidad Alberto Hurtado. Correo electrónico: mfernand@uahurtado.cl 


\section{CARIDAD Y TEMOR: LÍNEAS DE CONTINUIDAD EN LA SEMÁNTICA COLONIAL Y REPUBLICANA DEL PUEBLO}

Entre la última mitad del siglo XVIII y la primera del siglo XIX el uso político del concepto de pueblo en Chile experimentó una continuidad de sentido que es posible evidenciar con claridad una vez pasadas las décadas revolucionarias -constructoras de significados contingentes al mismo tiempo que fugacesque operaron como bisagra del periodo aquí comprendido. De forma general, con respecto al pueblo entendido como el conjunto de las clases menesterosas -el bajo pueblo-, la acepción más recurrida estará organizada de acuerdo al binomio caridad/peligrosidad, que se presentará como un doble desafío para las administraciones coloniales y republicanas. En un movimiento de significación opuesto a esta estática, la profundización conceptual y la multiplicación de los sentidos explícitos del término se desenvolverá en el plano de la representación política, como agentes de decisión y delegación de soberanía, como criterio fundante de esta una vez acontecido el proceso independentista, verdadero eje de transformación conceptual que prologará el desarrollo de interpretaciones conservadoras, liberales, federales y republicanas de los conceptos reseñados, en un proceso de oposiciones que encontrará su punto de convergencia en el consenso ilustrado de la amenaza representada por la parte más pobre del pueblo y sus inclinaciones contrarias al orden oligárquico, así como en la creencia liberal en la posibilidad de regeneración que el inevitable paso por la revolución debía representar.

Así, el variopinto conjunto de conceptualizaciones de pueblo que dio a luz la retórica -y las urgencias políticas y militares- del proceso de emancipación, aquellas que fijaban al conjunto de los chilenos y chilenas, o solo a su parte "más sana", o también a los más desprotegidos, no fueron sino un paréntesis, un margen de locuacidad -semantizado desde el liberalismo, las intenciones ilustradas, la caridad, la patria e incluso la revolución- que al mismo tiempo que fue abandonado una vez consolidada la república autoritaria, se mantuvo como un arcón de representaciones, de expectativas discursivas, cada vez que sectores políticamente disidentes se alzaron en armas o quisieron manifestar al régimen conservador su inquina y mal gobierno. De esa manera, el concepto de pueblo representó, en el marco de los cien años en que se concentra este escrito, una multitud de significados emparentados mucho más con la interpretación que los distintos emisores (coloniales o republicanos, patriotas, conservadores y liberales) querían trasmitir, que con la experiencia efectiva de aquellos a los que -alternadamente, con salidas y entradas en escena, jugando papeles a fin de cuentas contradictorios- una y otra vez se proponía representar. En este sentido, no solo la ficción de la soberanía popular fue impregnada al concepto pueblo, sino que en la alternancia de sus significados, en su reelaboración contextual, incluso esta fue cambiando con independencia de, nuevamente, las prácticas y expectativas de la población que el pueblo abarcaba.

Como expresión de una continuidad semántica de largo aliento, así como matriz conceptual de significado observable en los escritos de las administraciones coloniales y la élite criolla y posteriormente republicana, las acepciones relacionadas al 
concepto pueblo que las sucesivas ediciones del Diccionario de la Lengua Castellana entre 1780 y 1843 contienen son un interesante derrotero por el cual adentrarse a la reflexión histórica sobre el concepto. De esa forma, pueblo será entendido a la vez como el lugar poblado de gente, como el conjunto de habitantes y, en particular, aquellos definidos como "la gente común y ordinaria de alguna ciudad, o población, a distinción de los nobles" . Es decir, aquellos que no eran "ilustres, claros y conocidos por su sangre", aquellos contrapuestos -en tanto viles y deshonrados- a lo honroso y estimable, excelente y aventajado que representaba el segmento noble de cada localidad ${ }^{2}$. Ya no por oposición, el pueblo está definido por su referencia a lo común, a "lo que no siendo privativo de ninguno, pertenece, o se extiende, a muchos", a aquello "ordinario, vulgar, frecuente y muy sabido". La voz del pueblo como entrada del Diccionario persistirá hasta la edición de 1803 como expresión así de soberanía unánime como de sabiduría conforme, cuando asociada a la voz de Dios, la indique como frase proverbial "que enseña, que lo que casi todos dicen regularmente es verdad"3. En esta acepción particular asimilable al sentido común será contestada por la última historiografía colonial, en tanto José Pérez García planteaba su propia Historia Militar, Civil y Sagrada del Reino de Chile... como opuesta en su factura a aquellas que "nos vierten cosas que se han escrito de hablillas del vulgo"4, entendidas también como rumores, "pifias y risas de toda laya de gentes" que podían quitar su dignidad de regidor a un criollo indigno del Cabildo por el desorden de su comportamiento particular ${ }^{5}$.

Como definición de significado social, lo común es lo bajo, "de inferior clase y despreciable", al mismo tiempo que "todo el pueblo de cualquier provincia, ciudad villa o lugar"6. Esta definición de carácter inclusivo, que asimilaba al pueblo con la totalidad de la población, obtiene una especificidad conceptual más definida al ponerla en relación con los conceptos asociados a la noción social del pueblo, en tanto que los redactores de la Real Academia Española no dejaron de vincularlo explícitamente a la gente bajuna, "la más despreciable de la República", la gente baja, de poca estimación, el vulgo o plebe, la gentualla, la gentecilla, aquella "baja, despreciable y de ruines costumbres"7, donde ruin es definido como "bajo y despreciable", a la vez que como de "pocas obligaciones, malas costumbres y procedimientos" 8 . Términos como populacho ("lo más ínfimo de la plebe") y bahorrina,

1 Diccionario de la Lengua Castellana compuesto por la Real Academia Española (en adelante $D R A E)$, Madrid, Joaquín Ibarra, 1780, 759.

Ibid., 649.

Ibid., 759

José Pérez García, Historia Natural Militar, Civil y Sagrada del Reino de Chile en su descubrimiento, conquista, gobierno, población, predicación evangélica, erección de catedrales y pacificación, Santiago, Impr. del Ferrocarril, Colección de historiadores de Chile y de documentos relativos a la historia nacional, vol. 22, 1861 .

Actas del Cabildo de Santiago (en adelante ACS), 1785, 63

DRAE 1780, 251.

Ibid., 499.

Ibid., 813 .

Ibid., 737. 
como "conjunto de gente soez y ruin"10 se emparentan unos a otros, siendo a la larga comprendidos por los más frecuentes vulgo - "el común de la gente popular, la plebe", "el común modo de discurrir, u opinar de la gente baja, o que sabe poco"11 - y plebe, entendida como "la gente común y baja del pueblo"12, en donde bajo debe ser entendido como "lo humilde, lo despreciable, abatido"13. Antes que virtud, en este contexto humildad representa la "bajeza de nacimiento, o de cualquier especie" 14 .

Es decir, y de forma recurrente, la asociación desde la perspectiva de totalidad del pueblo como agente aglutinador y regulador de la identidad local fue profundizada conceptualmente como denominación de los sectores sociales pobres y desprovistos de cualquier privilegio, aquellos que la edición del Diccionario de 1832 denominará como "estado llano" -en referencia al vocablo plebe ${ }^{15}$, que mantenía hasta 1843 su oposición original con respecto a los nobles ${ }^{16}$. Esta pobreza fue entendida, por parte de las administraciones criollas y coloniales, desde la doble faz de la caridad cristiana y el desprecio de estamento. Caridad, como expresan las Actas del Cabildo de Santiago cuando anotan la concurrencia de los vecinos en donar "cuantiosa porción", para demostrar a las provincias la misión de la capital de "ser la primera en el buen ejemplo para excitar más la caridad"17. En sus páginas, las Actas mencionan la necesidad de dineros para "la manutención de huérfanos, pobres y arrepentidas" 18 , aquellos que ante el alza del pan hacían llegar sus clamores a los oídos de la autoridad ${ }^{19}$, o que como enfermos debían ser acogidos en el Hospital del Señor San Juan de Dios, debiendo certificar su alimentación suficiente un capitular del Cabildo ${ }^{20}$. En un contexto de sequía y epidemias, la misma institución solicitaba del obispo, "que como benigno pastor dispense el pueblo pueda comer de carne en la presente cuaresma", por la escasez de alimento y la debilidad de los enfermos ${ }^{21}$, "principalmente los pobres, por falta de medicinas y abrigos" 22 . Como significativa continuidad, ya en el proceso de la revolución emancipadora, la administración criolla manifestó su intención caritativa atendiendo "a la miseria de los pobres, deseando prestar algún consuelo a las familias desamparadas, teniendo en consideración cuanto contribuya a promover la pureza de las costumbres" 23 , estimándose esta última tarea bajo la figura de la policía, entendida como "del mayor interés de




los pueblos pues uno de sus grandes objetos es la salud pública", particularmente importante para reformar "el desaseo y miseria de la plebe" 24 y demostrar con ello el "paternal desvelo del superior gobierno" 25 .

La conceptuación del pueblo como agente de desorden se aprecia, como reflejo inseparable del pueblo motivo de caridad, en su vinculación con la "gente plebe, que es quien usa" de los embriagantes para provocar "mil pendencias y disgustos de que resultan muertes y desastres con grave perjuicio de la causa pública", por lo que "toda aquella persona que se supiese usa de esta bebida sea castigada severamente según su calidad"26. Asociado con la multitud y el desorden, el pueblo peligroso se aglomeraba en los mercados, perdiéndose "los criados por las ventas de licores, juegos y otros vicios que no son de preciso alimento" y que los ponían en contacto con los "viciosos y mal entretenidos" miembros de la estofa más baja del populacho ${ }^{27}$, aquellos que fomentaban la ociosidad y todos los desordenes "que han querido precaver las leyes mandadas observar por las superioridades" 28 . Pero la misma plebe criminal y beoda, como pueblo recibía la atención del Cabildo que se inclinaba "sobre el pobre y miserable estado en que se hallan reducidos los pobres presos de la cárcel, sin tener con qué darles de comer, quedándose muchos días sin un pedazo de pan por ser contingente la corta limosna que sufragan los piadosos diariamente para su manutención" 29 . Poco después, se emprendería la construcción de una nueva cárcel, "para libertar a los infelices presidiarios de la antigua caverna y mazmorra en que yacían" purgando sus delitos ${ }^{30}$.

Ambos ejercicios de conceptualización referidos al pueblo -la policía y la caridad- apuntaban en el último cuarto de siglo colonial al mismo objetivo de regeneración y fortalecimiento de la población, como un agente económico efectivo de la noción ilustrada de progreso que la administración borbónica y criolla sostenía como proyecto modernizador: la persecución de la vagancia, la educación de los pobres y la exaltación de las ventajas económicas del territorio necesarias de explotar por un pueblo vigoroso y sobrio serán recurrentes como articulaciones de una conceptualización de la gente común, entendida como recurso económico desaprovechado por la ignorancia y la ausencia de un destino común ${ }^{31}$.


pueblo en el pensamiento de los precursores de 1810", en Anales de la Universidad de Chile 120, Santiago, 1960, 36-49. 


\section{SOBERANÍA, CATECISMO Y REVOLUCIÓN: LAS TAREAS DEL PUEBLO EN LA COYUNTURA DE LA EMANCIPACIÓN}

El inicio y desarrollo de la coyuntura revolucionaria de 1810-1818 reportará notorias modificaciones en el uso del concepto pueblo, en tanto se establecerá en este la función soberana de construir y defender la nueva legitimidad republicana. Con un discurso cada vez más radicalizado, el temor al pueblo será reemplazado por su exaltación revolucionaria, al mismo tiempo que en los pueblos -en su acepción referida a población y localidad- descansará el poder de decisión y la organización electoral de la naciente república. En tiempos de revuelta y aceleración temporal, los significados y profundizaciones conceptuales del pueblo se multiplican, adquiriendo por ello una pluralidad de sentidos en permanente convivencia y comunicación.

La coyuntura histórica de la invasión francesa y la guerra en España motivaron la apelación, por parte primero de las autoridades coloniales y luego de la administración criolla, a la figura del pueblo como defensor de la legitimidad del Rey ante la amenaza de la usurpación extranjera. De esa forma, en mayo de 1810 los regidores del Cabildo anotaban la imprudencia de enviar las lanzas de la ciudad a la Península, en tanto "el pueblo clama porque en las críticas circunstancias en que se halla se le despoje así de las únicas armas que tiene" y que podría poner en acción ante la agresión napoleónica ${ }^{32}$. De forma similar, el desarrollo de los acontecimientos locales puso en evidencia, de acuerdo con la misma fuente, las amenazas que para la unidad del pueblo representaba el desorden gubernativo. Así, en una larga capitulación que celebraba la renuncia del último gobernador colonial, los notables del Cabildo argumentaban, en agosto de 1810, tanto "la turbación y zozobra que experimentó este pueblo en los días precedentes a la abdicación que hizo del Gobierno el señor ex -Presidente Francisco Antonio García Carrasco", como "las miras hostiles y de violencia que proyectaba contra este pueblo" el mismo funcionario. Al hacer el relato de las tropelías y crímenes del último gobernador, los regidores no dejaron de hacer referencia a la repulsa que estos provocaban en "este honrado pueblo", opuesto de forma mayoritaria a la "gente más despreciable del pueblo" en que García Carrasco se apoyaba para sus conspiraciones, amenazando con rumores de que "se armaba la plebe para que saquease la capital ya que aparecían escuadrones de gente de las campañas"33, aquellos dueños "de la insolencia de los viles, cuando se ven sostenidos por la autoridad" 34 . Por primera vez, "todo el pueblo de la realidad del hecho" se congregaba frente a la plaza frente al Cabildo en solicitud de armonía y orden político, pero lejos de la insurrección no meditada, unido a la nobleza cabildante, "dando una prueba de su singular modera-

32 ACS $1810,7$.

33 Ibid., 26-34.

34 "Motivos que ocasionaron la instalación de la Junta de Gobierno en Chile" [1811], citado en Espíritu de la Prensa Chilena, Colección de artículos escogidos de la misma desde el principio de la Revolución hasta la época presente (en adelante EPCh), Santiago, Imprenta del Comercio, 1847, tomo I, 10 . 
ción", del "ánimo de este pacífico pueblo" que actuaba con "inspirada justicia y horror de la falsedad" representada por los funcionarios, "que eran odiosos y sospechosos a todo el pueblo" 35 . Era aquella "la porción más sana del pueblo"36, la que podía proclamar "que todos los hombres que componemos el pueblo, tenemos igual derecho a nuestra conservación, a nuestra felicidad y a nuestra fortuna" 37.

El ingreso del pueblo a la arena política implicó, a juicio de la aristocracia criolla representada en el Cabildo, el fraccionamiento del pueblo, en tanto en la víspera de la formación de la Junta de Gobierno que daría inicio al proceso de emancipación ya se denunciaba con alarma "los partidos y divisiones del pueblo, con que peligra la tranquilidad pública y buen orden", siendo urgente hallar las medidas que arbitrasen el modo "más conveniente para sosegar la fermentación con que se veía el pueblo con riesgo de desgracias" 38 . De esa forma, se convenía en la instalación de la Junta de Gobierno -siempre a nombre del Rey cautivo-, como mecanismo de conjurar los rumores públicos "que tenían al pueblo en inquietud" 39 . En ese contexto, se solicitará al pueblo el rechazo "de la debilidad, del egoísmo, de la desunión e intriga" ${ }^{40}$, todas instancias aprovechadas por

"la astucia de algunos individuos sobre la falta de ilustración de la masa popular [...] el pueblo entusiasmado por la libertad, tal vez trabaja para destruirla, sin conocer la naturaleza de los medios, que un astuto ambicioso le hace adaptar por conveniente. En esta situación solo la virtud es perseguida, y solo el vicio tiene lugar en las asambleas: los bandos fomentan la división, i esta termina en guerras civiles, que disponen los ánimos a recibir con gusto la esclavitud. Consultemos estas verdades con la historia, que es el mejor libro de la política"41.

División de la unidad pública, inquietud popular y ausencia de ilustración política fueron representadas como las amenazas flagrantes al papel soberano de los pueblos en el nuevo tiempo que se habría ante sus ojos. Por ello, el objetivo central que buscaron los independentistas criollos fue la educación política del pueblo, la toma de conciencia así de sus derechos, como de sus deberes y sus enemigos. Para ello, la forma del catecismo político fue clave, en tanto con una redacción propedéutica y un claro ideario republicano, este tipo de folleto supuso al pueblo como su auditor predilecto ${ }^{42}$. En su Catecismo Político Christiano, José Amor de la Patria iniciaba el cuestionario del verdadero orden político apelando al hecho de que "la instrucción de la juventud es una de las bases más esenciales de la sociedad humana, sin ella los Pueblos son bárbaros y esclavos, y cargan eternamente el yugo

35 ACS $1810,26-34$

36 "Motivos que ocasionaron la instalación de la Junta de Gobierno en Chile" [1811], en EPCh, t. I, 10 .

37 Antonio José de Irizarri, "Sobre los gobiernos republicanos" [1813], en EPCh, t. II, 57.

38 ACS $1810,44-45$

39 Ibid., 47

$40 A C h, \mathrm{~N}^{\mathrm{o}} 12,30$ de abril de 1813 .

41 Irizarri, "Sobre los gobiernos republicanos", op . cit., t. II, 48.

42 Rafael Sagredo Baeza, De la Colonia a la República. Los catecismos políticos americanos, 1811-1827, Madrid, Fundación MAPFrE y Ediciones Doce Calles, 2009. 
de la servidumbre y de las preocupaciones". Por estar inmersos en la ignorancia "los Americanos, como si no fuesen hombres libres, dotados de razón y de sentido, han callado y se han mostrado indiferentes a los acontecimientos". Más aún, "han estado mudos, han estado ciegos; se han mostrado estúpidos, y sin razonar, sin discurrir, se han dejado regir con el azote y la palmeta como los niños de escuela". Esclavizados bajo el régimen despótico que usurpaba "la primitiva y divina autoridad de los Pueblos", estos "tienen que sufrir sus atrocidades a costa de la ruina del estado y de sus fortunas y vidas", en tanto

\begin{abstract}
"la Metrópoli abandona los Pueblos de América a la más espantosa ignorancia, ni cuida de su ilustración ni de los establecimientos útiles para su prosperidad: cuida también de destruirlos, cuando puede; y cuando tiene agotadas y destruidas las provincias con los impuestos y contribuciones exorbitantes, y con el comercio del monopolio, quiere que hasta los institutos de caridad, y todo cuanto se haga, sea a costa de los miserables Pueblos"43.
\end{abstract}

De tal forma, el pueblo que no quisiese gemir en la esclavitud, debía huir "de los reyes como el cordero huye de los lobos" 44 . Por oposición a ello, la regla máxima de los gobiernos emancipados debía comprender que "la salud del pueblo es la ley suprema", y su primera tarea el educarlo, dado que "la fortuna de los estados es inseparable de la de los pueblos, y que para hacer a los pueblos felices es preciso ilustrarlos" 45 .

De esa forma, el pensamiento emancipador vio en la ilustración del pueblo la responsabilidad de la soberanía de los pueblos, siempre y cuando "la virtud anime los votos de la multitud", en su cualidad de unidad de la representación política, como base del buen gobierno de corte republicano, encabezado por un "cuerpo, colegio, senado o congreso, cuyos individuos sirven a cierto tiempo, elegidos por los Pueblos", aquel gobierno "en que manda el Pueblo por medio de sus representantes o Diputados que elige, el único que conserva la dignidad y majestad del Pueblo"46. Se iniciaba así un fértil camino de reflexión política que supondrá la conceptualización del pueblo como base del orden republicano, aquel en el cual

"el Pueblo es Rey, y todo lo que hace lo hace en su beneficio, utilidad y conveniencia: sus Delegados, sus Diputados o Representantes mandan a su nombre, le responden de su conducta... Si no cumplen con sus deberes, el Pueblo los depone y nombra en su lugar otros que correspondan mejor a su confianza" 47 .

De forma similar, para los redactores del primer periódico chileno, "la autoridad suprema trae su origen del libre consentimiento de los pueblos, que podemos

43 José Amor de la Patria, Catecismo Político Christiano. Dispuesto para la instrucción de la juventud de los pueblos libres de la América Meridional, Santiago, s.n., 1810.

44 Irizarri, "Sobre los gobiernos republicanos", op. cit., t. II, 45.

$45 A C h, \mathrm{~N}^{\circ} 1,13$ de febrero de 1812.

46 Irizarri, "Sobre los gobiernos republicanos", op. cit., t. II, 48.

47 Amor de la Patria, op. cit. 
llamar pacto o alianza social" en la cual "los contratantes son el pueblo y la autoridad ejecutiva" 48 . En una fase ulterior del proceso emancipador, José de Irizarri, al escribir sobre los gobiernos republicanos, indicaba que "no hay otro poder que el que compone el pueblo vasallo, i soberano al mismo tiempo", y por ello "el pueblo debe velar sobre la conducta de los mandatarios, para impedir el abuso, que puede hacerse del poder" 49 .

Esta vinculación estrecha entre los pueblos y sus representantes -basada en la convivencia conceptual entre un pueblo soberano y juez de sus representantes y unos pueblos que legitiman y eligen a estos- operó como la matriz original de construcción de un orden político novedoso, en donde la soberanía del pueblo y de los pueblos era el rasgo fundante de toda sociedad política, en tanto "los pueblos han existido antes que sus leyes" $" 50$ y por ello son la fuente de su redacción y la cesión que representa cualquier gobierno, aun aquel despótico, debido a que "el Pueblo que ha conferido a los Reyes el poder de mandar puede, como todo poderdante, revocar sus poderes y nombrar otros guardianes que mejor correspondan a la felicidad común". En el caso específico de la desaparición del monarca, "la autoridad vuelve al Pueblo de donde salió, vuelve a la fuente pura y primitiva de donde emanó, y el Pueblo es el único que tiene autoridad para nombrar o instituir un nuevo Rey, o para darse la forma de gobierno que mejor le acomode para su prosperidad". Es decir, en la coyuntura de una búsqueda de legitimidad originaria, el pueblo fue conceptualizado como la palanca que movilizaba a la nueva etapa histórica que se avecinaba: en sus manos descansaba la posibilidad de la libertad, en la acción "del Pueblo numeroso, del Pueblo valiente, del Pueblo de sabios" radicaba la génesis de un nuevo orden ${ }^{51}$. Esta tarea fue conceptuada en tanto facultad inherente al pueblo, como una responsabilidad de carácter histórico, a la cual "la participación de esta suerte os llama ;oh pueblo de Chile! El inevitable curso de los sucesos", aquellos sucesos que avecinaban "un tiempo, como lo han tenido y tendrán todas las naciones, de esplendor y de grandeza; que ocupaseis un lugar ilustre en la historia del mundo, y que se dijese algún día, la República, la Potencia de Chile, la Majestad del Pueblo Chileno" 52 . Para merecer el destino que la historia les deparaba, los pueblos debían manifestar cualidades enaltecedoras, "sentimientos heroicos, altos intentos, virtudes sublimes para que conservéis vuestra dignidad: nada de eso se necesitaba para ser esclavos" 53 . Solo el auxilio de la ilustración

$48 A C h, \mathrm{~N}^{\circ} 1,13$ de febrero de 1812.

49 Irizarri, "Sobre los gobiernos republicanos", op. cit., t. II, 54 y 59.

$50 A C h, \mathrm{~N}^{\circ} 2,20$ de febrero de 1812 .

51 Amor de la Patria, op. cit. La crítica histórica al concepto de soberanía popular -por medio de la reconstrucción de su proceso de generación en mundo atlántico entre la segunda mitad del siglo XVII y fines del XVIII- se encuentra en el lúcido estudio de Edmund S. Morgan, La invención del pueblo. El surgimiento de la soberanía popular en Inglaterra y Estados Unidos, Buenos Aires, Siglo XXI, 2006.

52 Quirino Lemáchez, "Proclama de Quirino Lemáchez”, en Camilo Henríquez y Juan Martínez de Rozas, Páginas de la independencia nacional, Santiago, Editorial del Pacífico, Instituto de Estudios Políticos, 1976.

$53 A C h, \mathrm{~N}^{\circ} 1,13$ de febrero de 1812 . 
patriota inscripta en el pueblo permitiría que este "despliegue de una vez su energía y entusiasmo; no sea solo otro pueblo americano quien ocupe las páginas de la historia y arrebate la admiración de los siglos: tenemos una obra activa en la obra más grande que hasta ahora presentan los fastos del universo" 54 .

Desde esta perspectiva, el fenómeno de la representación de los intereses y deseos del pueblo soberano marcó la elaboración de una conceptualización de la intimidad deseable entre este y sus representantes, quienes debían contar con "la disposición generosa de sacrificar su interés personal al interés universal del pueblo en el momento en que se constituye un hombre legislador por el voto y la confianza de sus ciudadanos, deja de existir por sí mismo, y no tiene más familia que la gran asociación del Estado", a la cual deberán servir lanzándose "en lo futuro, y leyendo en el pasado la historia de lo que está por venir, descubriendo los efectos en las causas" como legisladores-filósofos capaces de predecir "las revoluciones y ver en los sistemas gubernativos el principio oculto de su ruina y aniquilación" 55 . Atentos al arte de la prognosis y el devenir de los tiempos, como eruditos capaces de leer en las sombras del pasado las luces del porvenir, la productividad política de los grupos dirigentes, de aquellos desprendidos de sus intereses por la búsqueda del bienestar de las mayorías, radicaba así tanto en la representación que ejercían a nombre del pueblo, como en la sapiencia que la ilustración había impreso en ellos, los primeros entre los republicanos, los padres protectores de una población infantil y a ratos decabellada. Sin embargo, de forma temprana en la coyuntura independentista se alzaron voces que pusieron en cuestión tanto la naturaleza como la calidad de la representación que las élites criollas podían ejercer en relación a los "verdaderos" intereses del pueblo. En este sentido, la Proclama revolucionaria del padre franciscano Fray Antonio Orihuela es muy clara al subrayar dos aspectos hasta ese momento ausentes en las declaraciones discursivas que hasta aquí hemos citado. En primer lugar, Orihuela consideró que al concebirse la categoría del pueblo debía discriminarse tajantemente entre aquellos "nobles, empleados y títulos que sostienen el lujo con vuestro sudor y se alimentan de vuestra sangre", y

"los miserables hijos del país, que se hallaban sin giro alguno para subsistir por la tiranía y despotismo del gobierno [...] los artesanos, reducidos a ganar escasamente el pan de cada día, después de inmensos sudores y fatigas; los labradores, que incesantemente trabajan en el cultivo de pocas simientes para sus amos y morir ellos de hambre, dejando infinitos campos vírgenes, porque les era prohibido sembrar tabaco, lino y otras especies, cuya cosecha hubiera pagado bien su trabajo; de los pobres mineros, sepultados en las entrañas de la tierra todo el año para alimentar la codicia de los europeos" 56 .

54 Carta anónima a El Monitor Araucano, 11 de noviembre de 1813, en EPCh, t. II, 295.

55 Quirino Lemáchez, op. cit.

56 "Proclama revolucionaria del padre franciscano Fray Antonio Orihuela" [1811], reproducida en Sergio Grez, La "Cuestión Social" en Chile. Ideas, debates y precursores (1804-1902), Santiago, DIBAM, 1995, 51-55. 
En segundo lugar, el fraile cuestionó la posibilidad misma de la representación política que la élite se autoinvestía, advirtiendo a los artesanos y trabajadores populares sobre tal engaño, fruto tan solo de las "sirenas mentirosas que abusaban de vuestro nombre para descuidaros con la lisonja y haceros víctimas de su ambición, después instrumento para sus maquinaciones pérfidas”. Maquinaciones las cuales se implementaban -desde la misma articulación de la Junta de Gobierno y en cada elección de diputados realizada- por medio de la selección exclusiva de criollos ricos y poderosos en las instancias de representación política. Como reacción ante ello, y en vistas a la recuperación de esta soberanía expropiada, Orihuela interpelaba al pueblo:

"Con vosotros hablo, infelices, los que formáis el bajo pueblo. Atended: Mientras vosotros sudáis en vuestros talleres; mientras gastáis vuestro sudor y fuerza sobre el arado; mientras veláis con el fusil al hombro, al agua, al sol y a todas las inclemencias del tiempo, esos señores condes, marqueses y cruzados duermen entre limpias sábanas y en mullidos colchones que les proporciona vuestra trabajo: se divierten en juegos y galanteos, prodigando el dinero que os chupan con diferentes arbitrios que no ignoráis; y no tienen otros cuidados que solicitar con el fruto de vuestros sudores, mayores empleos y rentas más pingües, que han de salir de vuestras miserables existencias, sin volveros siquiera el menor agradecimiento, antes sí, desprecios, ultrajes, baldones y opresión. Despertad, pues, y reclamad vuestros derechos usurpados. Borrad, si es posible, del número de los vivientes a esos seres malvados que se oponen a vuestra dicha, y levantad sobre sus ruinas un monumento eterno a la igualdad" 57 .

En otro momento de su exhortación, Orihuela califica de "sarracenos" a los criollos ricos motivo de su crítica, dejando con ello en evidencia el hecho de que el proceso de emancipación política promovió al mismo tiempo que la elaboración de un concepto del pueblo soberano, su antinomia en aquellos segmentos de sí o extranjeros opuestos a la causa de su libertad. Así, como entidad enemiga se entendió al español, pueblo "vasallo y esclavo", atado a todo aquello que la Independencia buscaba anular ${ }^{58}$, y que se veía compensado de alguna forma en aquel "pueblo magnánimo que combate por su libertad" en contra de los franceses y todos aquellos "apóstatas de la más bella de las causas" 59 . Esos "españoles que se criaron entre la miserable chusma de los pueblos de la Península, a quienes les negó la naturaleza la luz de la razón con más rigor que a ningún otro populacho"60. Ya en un contexto de guerra, en un medio de prensa patriota podía leerse que los agentes del sarracenismo (refiriéndose a los monarquistas) eran en primer lugar las damas españolas, y luego sus criados, que divulgaban principios susceptibles de adquirir por aquel "vulgo que naturalmente se inclina a lo nuevo", gracias al cual "se engrosa día en día el partido antipatriótico" 61 , cuyos miembros españoles represen-

57 Idem.

58 Quirino Lemáchez, op. cit.

$59 A C h, \mathrm{~N}^{\circ} 11,23$ de abril de 1812

60 Antonio José de Irizarri, "Sobre la justicia de la revolución de América", en El Monitor Araucano, 14 de agosto de 1813, reproducido en EPCh, t. II, 7.

61 Vera i Pintado, "Carta al editor del Monitor", 21 de agosto de 1813, en EPCh, t. II, 157. 
taban un "fermento o levadura diabólica", a la cual una parte del pueblo entregaba el carácter de humanidad que un lector anónimo consideraba no merecían por desear "la muerte, la infamia y todos los males a unos pueblos, que no le han hecho más daño que haberlo vestido cuando vino de su tierra en pelota [desnudo]; haberlo curado en sus hospitales, etc." 62 .

Ante esos enemigos y frente la amenaza siempre presente del desorden y la anarquía, inherente al propio pueblo, los líderes de la Independencia conceptuarán a este $-\mathrm{y}$ tras ellos los redactores conservadores y liberales- como en estado de infancia, de ausencia de ilustración que hacía de la libertad

"un alimento de digestión difícil, y el pueblo no está preparado para ella, como no tiene principios, miras ni proyectos, pasará tal vez de la esclavitud a la anarquía, o tomará un movimiento incierto y vacilante en que cada paso sea un absurdo. Se pronunciará con entusiasmo la voz de libertad, pero ni se conocerá su verdadero sentido, ni se sabrá el modo de conservarla" 63 .

Similar situación de infancia explicaba el hecho de "que nuestros pueblos no tomarán todo el interés que debían por su libertad"64, y que peor aún, pudiesen volver al despotismo si no contaban con el auxilio de la ilustración, debido a la

"licencia dañosa de los pueblos [...] el más firme apoyo de las repúblicas es la ilustración y la virtud; i con dolor de mi alma siento, que aquel pueblo en donde no se encuentran estas cualidades, ni puede ser republicano, ni le conviene pensarlo: ese tal solo debe ser menos infeliz cuando se halle regido por un déspota" 65 .

\section{Al mismo tiempo, la ausencia de ilustración promovía}

"la indiferencia de los pueblos, que como si nada les importase el bien y el mal, dejan pasar sobre sus cabezas todas las desgracias, que evitarían, si conociesen su poder y sus obligaciones. La ignorancia de los pueblos solo es conveniente al interés de los tiranos; i por esto se empeñan en apartar de sus dominios todo lo que pueda conducir a la ilustración de sus esclavos; pero en las repúblicas, en donde no hai más soberano que el pueblo, i en donde solo éste debe juzgar de la felicidad o del peligro a que pueden conducirlo, es indispensable que conozca cuanto malo i cuanto bueno puede haber en las artes de los políticos" 66 .

62 “Carta anónima al editor del Monitor”, sábado 13 de noviembre de 1813, en EPCh, t. II, 296.

$63 A C h, \mathrm{~N}^{\circ} 2,20$ de febrero de 1812. Como metafórico remedio -o más bien prueba de superación- de esta puerilidad inherente al pueblo privado de ilustración, una decena de números más adelante desde la misma Aurora de Chile se proyectaba conceptualmente esta superación en la posibilidad de integrar a otros pueblos - aún menos ilustrados- en la comunidad de la nación: tal será el caso de la incorporación al cuerpo político chileno del mundo mapuche, entendido como una entidad nueva y por ello "dispuesta a ser ilustrada", por medio de " una legislación justa e imparcial, y con la participación de sus derechos, honores y ventajas [...] los modales se comunican, los pueblos, lo mismo que los individuos, están sujetos a la influencia del ejemplo: adquieren costumbres y decencia con la cercanía, comercio y trato de los pueblos cultos". $A C h, \mathrm{~N}^{\circ} 12,30$ de abril de 1812 .

64 Irizarri, "Sobre la justicia de la revolución de América", op. cit., t. II, 18.

65 Antonio José de Irizarri, "Sobre el origen i la naturaleza de las monarquías", en El Monitor Araucano, 11 de septiembre de 1813, en EPCh, t. II, 52.

66 Irizarri, "Sobre los gobiernos republicanos", op. cit. 
Junto a esta noción negativa de inexperiencia política del pueblo recientemente emancipado, en la conceptualización patriota prevalecerá una perspectiva que relacionaba esta infancia política con la idea de un "pueblo nuevo", que superando los desórdenes de la revolución, buscaba un modelo de organización política acorde a sus propias necesidades. Sin embargo, la irrupción de la guerra provocada por la restauración monárquica hará de este "pueblo nuevo" una base de sacrificio y valor que caracterizará el significado conceptual del pueblo. En una proclama del cabildo de Santiago, en abril de 1813, se convocaba a un "pueblo que quiere ser libre", en cuyo rostro se veía "el fuego, que brota de vuestro semblante, capaz de aterrar a esos mercenarios viles", un pueblo capaz de salvar "a toda la América Meridional, amenazada en nuestro territorio"67. Siempre en un contexto bélico, se confiaba en que las victorias militares "harán conocer al mundo lo que vale el Pueblo de Chile, y los justos derechos que tiene a su libertad"68, y fray Camilo Henríquez advertía que

"hasta ahora apenas presenta el mundo un pueblo más afortunado que el de Chile. Rodeado por todas partes de los dones más preciosos de la naturaleza, bajo un cielo sereno i hermosísimo, i pisando el suelo más feraz, cuyas entrañas encierran tantos tesoros, restaba que el mar que forma uno de sus límites, concurriese a su dicha i engrandecimiento. Por esta parte le entrarán la industria i las luces, atraídas de la libertad i de las leyes, i llamadas por la fama. Los pueblos necesitan gozar de cierta reputación: la gloria de las armas precede siempre la de los talentos; y todas las artes, todos los adelantos sucesivos, y todas las virtudes pacíficas se apoyan sobre la fortaleza militar" ${ }^{\circ 9}$.

Así como la guerra era definida como "popular" por estar inspirada en "los más caros intereses de los hombres" en oposición a la "potencia y gloria de un príncipe"70, la construcción de la reputación y la fama militar de un pueblo era el producto de la victoria: "Pueblos! Si somos vencidos nos aguarda la muerte, la infamia y la desolación. Si vencemos, seremos libres, i felices, i el mundo se llenará del esplendor de nuestro nombre" ${ }^{71}$. Esta asociación entre marcialidad e

67 "Una gavilla de esclavos, auxiliados de nuestros enemigos domésticos, ha invadido Concepción. ¿Sufriréis que duren en vuestro territorio? ¡No! El fuego, que brota de vuestro semblante es capaz de aterrar a esos mercenarios viles. Franqueáis vuestros bienes: os alistáis en el ejército: tomáis cuantos recursos dicta el patriotismo más acendrado $[\ldots]$

$[\ldots]$ ¿Quién resiste a los esfuerzos de un pueblo, que quiere ser libre? [...]

[...] ¡Ciudadanos todos! Haced conocer al mundo la recíproca e inalterable unión i confianza, que existe felizmente entre el gobierno i el pueblo. Estrecho enlace de opinión i de fuerza nos coronará de gloria salvando a toda la América Meridional, amenazada en nuestro territorio". "Proclama del cabildo de Santiago a los pueblos", 24 de abril de 1813, en EPCh, t. II, 63.

68 "El gobierno a los pueblos", en El Monitor Araucano, 10 de junio de 1813, en EPCh, t. II, 98.

69 El Monitor Araucano, 15 de junio de 1813, en EPCh, t. II, 101.

70 “.... que una guerra popular en que ha de decidirse del honor i seguridad del pueblo, de la honra o la infamia de tantas familias comprometidas, i en fin, de los más caros intereses de los hombres, ha de tener más apoyo, ha de conmover más vivamente el corazón i el ánimo, que las guerras ordinarias, cuyo único resultado suele ser aumentar la potencia i gloria de un príncipe". "Discurso en el aniversario de la instalación del nuevo Gobierno, por Cayo Horacio", en El Monitor Araucano, 18 de septiembre de 1813, en EPCh, t. II, 196.

71 "Proclama del gobierno a los pueblos", en El Monitor Araucano, 22 de junio de 1813, EPCh, t. II, 112 . 
identidad del pueblo vinculó, con el avance de la guerra y sus sacrificios, la constitución de un pueblo representado como varón, en tanto la emancipación era "causa que ha sido siempre la de los grandes hombres y solo la emprendido pueblos esforzados y varoniles"72. De forma evidente, la vida misma del pueblo descansaba en las armas de sus soldados, y el gobierno se dirigía a ellos invocando al pueblo:

"Militares! sois la fuerza del pueblo, los defensores de sus derechos, i los conquistadores de su libertad [...] El reconocimiento del pueblo será eterno para sus defensores [...] El pueblo no perdonará sacrificios ni gastos para sosteneros: ya no se demorarán las pagas, i todos serán alimentados i vestidos perfectamente. El pueblo tiene suficientes fondos con tal que se administren con economía [...] Vais a decidir si el pueblo ha de ser libre, o ha de ser esclavo, i vuestra conducta debe ser digna de la fuerza armada de un pueblo cristiano, humano i justo. Haced amable a las provincias la santa causa que sostenéis; restableced la opinión del pueblo"73.

El tránsito de la guerra, el "paso por tempestades, y aun por la oscuridad de la noche" fueron entendidos como factor de maduración del pueblo, como parte de aquel "renacimiento político" que se le asignaba en 1813, capaz tanto de asumir la dureza de la guerra como de promover la ilustración, de forjarse, de "formar hombres, soldados, oficiales, generales, ciudadanos, transformando un país de conquista en un pueblo capaz de resistir con gloria". El éxito en la batalla revelaría "si por la disciplina i la virtud, unidas al valor, es digna la juventud armada de llamarse milicia de un pueblo virtuoso; i si por los sacrificios y esfuerzos merece este pueblo ser libre" 74 .

La radicalización del proceso emancipador producto de la guerra insistió en el topos de la ilustración del pueblo como un factor imprescindible de su liberación. El himno cantado en la inauguración del Instituto Nacional, primera institución educativa de la República versaba entre sus estrofas: "No hai libertad sin luces / Al pueblo oscurecido / De sus grillos el ruido / Jamás le despertó / La gran Filosofía / Del Error ha triunfado / I alegre ha levantado / Su augusto pabellón"75. Del mismo modo, y ante la urgencia de constituir una Biblioteca Nacional con el auxilio de los particulares, se expresaba: "aún no es esta biblioteca digna del pueblo que marcha protegido de la providencia por todas las sendas de la gloria, i es también preciso que conozca todo el mundo el interés que tiene cada ciudadano en la beneficencia de los demás, i que Chile compone una sola familia"76. Por lo mismo, aquella parte del pueblo que rechazaba la ilustración -identificada como partidaria de la monarquía- era calificada por Camilo Henríquez como "raro monstruo", en 1813:

72 Camilo Henríquez, en El Monitor Araucano, 2 de septiembre de 1813.

73 José Miguel Infante, Agustín Eyzaguirre y Juan Egaña, "El Gobierno a la División que parte de la capital", El Monitor Araucano, 9 de septiembre de 1813, EPCh, t. II, 187.

74 "Discurso en el aniversario de la instalación del nuevo Gobierno, por Cayo Horacio", op. cit., t. II, 194 .

75 "Himno que se cantó en la apertura solemne del Instituto Nacional de Chile, su autor el ciudadano Vera", El Monitor Araucano, 12 de agosto de 1813, en EPCh, t. II, 143.

76 "El Gobierno a los pueblos", El Monitor Araucano, 19 de agosto de 1813, en EPCh, t. II, 155. 
"No obstante con la constancia

Se vencen los imposibles,

I por audacia i firmeza

Se hacen los pueblos felices.

Tú de todo te acobardas,

E inspiras consternación.

¡Raro monstruo! ¡buen primor!

Bien sabes tú que las ciencias

I útiles conocimientos

Logrados en la lectura

Son la salud de los pueblos;

Mas nunca tomas un libro

Ni procuras tu instrucción.

¡Raro monstruo! ¡buen primor!

Vacilará el edificio

Más hermoso de la tierra,

Si no inspiras entusiasmo,

I haces amar tus ideas.

¿Una verdad tan palpable,

I apoyada en la experiencia,

Aún no te ha hecho impresión?

¡Raro monstruo! ¡buen primor!”77.

La conquista de la libertad política por las armas consolidaba conceptualmente el poder soberano del pueblo como base de la representación política, con referencia a la cual ya el contexto de las guerras de independencia permite observar una distancia entre el pueblo y aquellos que se suponen sus representantes, en tanto que "si el pueblo es el soberano, él debe hacer sus leyes, y nadie debe disputarle los actos de su soberanía", alejado de las "cosas metafísicas, de las palabras muy sonoras y delicadas" que abundaban entre los gobernantes ${ }^{78}$. Una vez concluida la guerra y desatadas las diferencias entre distintos sectores provinciales y políticos, aquellos que no ocupaban el gobierno recordaban a las autoridades que "nada es tan natural, ni tan en el orden de los sentimientos humanos como que un pueblo procure sustraerse de la ley que se le quiere imponer contra su voluntad, y que se exaspere cuando ve burladas sus más caras esperanzas", exasperación la cual inspiraba al redactor de El Liberal,

77 El Monitor Araucano, 30 de octubre de 1813, en EPCh, t. II, 276.

78 "Yo, i todos los hombres rudos como yo, no entendemos de cosas metafísicas, ni gustamos de palabras mui sonoras i delicadas: las obritas, las obritas son las que nos nutren, las que nos convencen. Mui poco nos importa, que nos digan las proclamas i los papeles públicos: sois libres: se acabó el despotismo: todos somos iguales: todos somos felices: vivimos en la más completa seguridad: el pueblo es soberano, i la ley de nuestras operaciones es la razón, la justicia. Todo esto es una jerigonza. ¿Corresponden las obras a las palabras? Aquí está el alma del negocio, i el negocio del alma. Si el pueblo es el soberano, él debe hacer sus leyes, i nadie debe disputarle los actos de su soberanía. Si un individuo del pueblo es libre, nadie debe echarle en cara que use de su libertad". El Monitor Araucano, 2 de octubre de 1813, en EPCh, t. II, 260-261. 
en 1824, a imaginar en la cumbre del patíbulo un mensaje que dijera "Magistrados, no sois los amos de los pueblos, si quebrantáis la ley ocuparéis este lugar"79, aludiendo así a la doble soberanía del pueblo y de su multiplicidad de identidades locales. El ataque a este tipo de representación plural por medio del federalismo será realizada poniendo entre las responsabilidades de los "representantes de los pueblos desengañarlos y hacerles conocer la imposibilidad de los medios y lo funesto de los resultados, hablándoles con franqueza y lealtad"80. Se insistía así en un tópico presente desde temprano en la construcción del orden republicano: la conceptualización de un doble compromiso: el del pueblo a la obediencia y el de sus gobernantes "al amor a la patria, que inspira el acierto y todas las virtudes sociales" 81 . Tras la emancipación, el Poder Legislativo -conformado por los legisladores, "Padres del Pueblo"- insistirá en el imperio de la ley como freno al poder del pueblo, en tanto este "conocía que sus derechos no consistían en el uso de un poder ilimitado, y ejercido aisladamente que podía precipitarle a la anarquía; y que su sólida felicidad estaba en el orden y en establecerse instituciones garantes, que bajo el imperio de las leyes le defendiesen de la arbitrariedad" 82 . En una puja en el fondo establecida entre un Ejecutivo centralista y sectores legislativos de ánimo federal, los últimos dejaban descansar la soberanía en los pueblos, que "bien pueden nombrar, para constituirse sus delegados o diputados porque no es posible hacer esto de otro modo, pero jamás es su intención, al darles tales poderes, desnudarse del último derecho que les queda a la sanción o repulsa de lo que sus comisionados hiciesen" 83 . En tono federalista, y ya en 1829 , desde provincias se levantaba la queja de que "ya hemos palpado que el código de nuestros derechos solo ha servido para que los mandatarios afiancen su poder, y con él atropellan las libertades de los pueblos, y aniquilan los ciudadanos que no les sirven de esclavos" $" 84$.

\section{SOBERANÍA VACÍA: LA RESTITUCIÓN DEL ORDEN CONSERVADOR}

Concluida la guerra, y persistiendo la alternancia de gobiernos teñidos de distinta inspiración política, el carácter obediente del pueblo fue visto como amenazado por el continuo cambio de administraciones, en tanto esta permanente mudanza despoja-

79 El Liberal, 3 de enero de 1824.

80 Agustín de Eyzaguirre, Señores diputados. La reunion de los Representantes del Pueblo en esta augusta Asamblea..., Santiago, Imprenta Nacional, 1823, 8.

81 "[...] hai deberes recíprocos entre los individuos del Estado de Chile i los de su Congreso Nacional, sin cuya observancia no puede alcanzarse la libertad i la felicidad pública. Los primeros están obligados a la obediencia; los segundos al amor a la patria, que inspira el acierto, i todas las virtudes sociales [...]". "Oración, que dijo en la solemne apertura del Supremo Congreso Nacional de Chile el ciudadano Henríquez. Diputado del mismo augusto cuerpo, en la Catedral de Santiago el día 4 de julio de 1811 ", en EPCh, t. II, 314.

82 Agustín de Eyzaguirre, op. cit., 1.

83 Francisco Antonio Pinto, Memoria del Ministro del Interior en contestación al Mensaje del Senado, Santiago de Chile, Imprenta Nacional, 1824, 9.

84 Junta Municipal de Los Andes a las autoridades de la República, Santiago, Imprenta de la Independencia, 1829. 
ba al gobierno "de aquel respeto que sea por hábito o convencimiento le tributan los pueblos", y facilitaba que en las "reuniones de pueblos" los "díscolos" se permitiesen "extraviar a la multitud". El orden solo podía ser mantenido tras "arrojar del país a los díscolos, a los facciosos que con pretexto de mejoras quieren desunirnos y extraviarnos, y castigar sin misericordia a los aventureros que sin gozar de los derechos de la ciudadanía toman la voz del pueblo para insultar al gobierno" ${ }^{85}$, recuperando este con ello la capacidad de las leyes para evitar "los desórdenes, las divisiones que van a hacer a los pueblos maldecir la hora en que salieron de su tranquila esclavitud" 86 . Idea similar era expresaba desde el Senado en 1824, en tanto en los pueblos "la frecuente variación de leyes, inspira la mayor desconfianza y desafecto a todas" 87 . En esos términos, se consolidaba una visión del pueblo como opuesto a los pueblos, en tanto la entidad de estos se expresaba en un plano abstracto, vinculado a la ideología. Como opuesto, el pueblo era relacionado a la materialidad de su cuidado, al orden de su gobierno, a la extirpación de sus vicios ${ }^{88}$.

En una coincidencia de fondo con esta interpretación autoritaria del orden, una vez alcanzada la emancipación política los sectores de la élite relacionados con el liberalismo responsabilizarán de la permanencia de gobiernos de corte autoritario y conservador a la persistencia del pueblo en las tradiciones políticas del monarquismo, como dejaba en evidencia la fábula del asno que, acostumbrado a la pesada carga de su yugo, no es capaz de dejarla a un lado cuando se le quitan, provocando con ello la ira del "libertador", que le increpa:

"Lección para los pueblos acostumbrados a soportar el peso de la tiranía.

Tenía un Borrico

El Tío Juan Rana

Lleno de tumores

De materia y lacras.

Todas las costillas

Tenía matadas

Tanto que el mirarle

Compasión causaba.

Verdad es que el pobre

Tenía una albarda

Vieja ya y raída,

Pero muy pesada.

85 Un Chileno, Contestación al Independiente, Santiago, junio 4 de 1821, Santiago, Imprenta Nacional, 1821, 12-13 y 19.

86 Agustín de Eyzaguirre, op. cit., 1.

87 Mensaje del Senado conservador y legislador de Chile a la Cámara, o Congreso Nacional convocado en cumplimiento del Senado Consulto de 21 de junio de 1824, Santiago, Imprenta Nacional, 1824, reproducido en Domingo Eyzaguirre, Clamor de la verdad y el orden, Santiago, Imprenta Nacional, 1825, 13.

88 Ibid., 14. 
Queriendo aliviarle El Tío Juan Rana, Le quitó de encima La pesada albarda.

Empero el Borrico Quiso recobrarla, Y le dijo el amo:

Mira que te mata.

No importa, responde El Asno: es pesada, Es verdad: me agobia, Me muele, mecaniza;

Pero ha tanto tiempo Que sufro su carga, Que ya acomodarme No puedo a dejarla.

Entonces furioso Le dijo Juan Rana, Echándole a cuestas La pesada albarda.

¡Ah bruto! Reniego De ti y de tu casta; Por tonto mereces Suerte tan infausta.

Pueblos oprimidos, Con vosotros habla Esta fabulita,

Que parece nada.

Si cuando los sabios

Con reformas tratan

De hacer llevaderas

Todas vuestras cargas,

Seguís el ejemplo Del Asno de Rana Merecéis por tontos, Suerte tan infausta" 89 . 
De forma similar, la referencia del concepto de pueblos a una clave política federal -en una nación marcada desde sus orígenes por un acendrado centralismose hará visible desde el inicio del proceso de emancipación, en tanto se anotaba ya en 1810 la idea de que "los Pueblos vivían felices en un gobierno federativo. Algunos aventureros atrevidos, y afortunados se apoderaron del mando, y los subyugaron" 90 . Con una clara intención de identificar a los pueblos como unidades de representación e identidad específicas, los bandos del Gobierno en el contexto de las guerras de independencia fueron dirigidos sistemáticamente a "los pueblos" Pasado el conflicto contra la restauración, la opción política federal fue sostenida en particular desde Concepción, conceptuada por los federalistas como "el baluarte de los demás pueblos de la República"92; y por sus opositores como "el monstruo precursor seguro de la esclavitud", que los pueblos equivocados en sus ideas cometían el error de abrazar ${ }^{93}$. El mismo Ramón Freire, el jefe federalista, acusará a los pueblos de no haber "alcanzado el premio de sus sacrificios, ni el fin con que se armaron contra la tiranía"94.

De forma algo más comprensiva, el federalismo y otros movimientos de oposición al gobierno podían ser disculpados por este como espasmos corrientes "en pueblos inexpertos y nuevos, agitados además por el calor de las pasiones que se desenvuelven en toda revolución" 95 . Sin embargo, con los conflictos originados por la disputa entre distintas opciones de organización del Estado, retornó la conceptualización del pueblo como entidad amenazada en su unidad política, en tanto "faltándoles el centro de unidad moral, que constituye el equilibrio de sus pretensiones, pronto se entregarán a los delirios de una perfección ideal, que arrastrándolos de abismo en abismo les hará sentir todo el peso de su desgraciada situación"96. Por ello, los adictos al orden fuerte del gobierno no dejaron de defender, a mediados de la década de 1820, la necesidad de "sofocar el espíritu de los partidos, y a hacer conocer al incauto e ignorante vulgo que solo en la unión recíproca debemos aguardar felicidad y éxito", entendiendo a estas facciones como "fantasma de tantos nombres y supuestos partidos, concitándolos de ese modo a armarse de puñales para despedazarse recíprocamente" 97 , o al menos a inhibir su "voluntad libre y espontánea" por el "fermento en el que suele entrar el Pueblo por medio de los partidos" 98 . Los mismos federalistas, una vez en el poder, rechazaron hobbesianos "choque de todos contra uno, o unos contra otros", de aquella "horrorosa anarquía que asoma desgraciadamente en este pueblo su espantosa cabeza, y el cuerpo de representantes de donde debía partir el

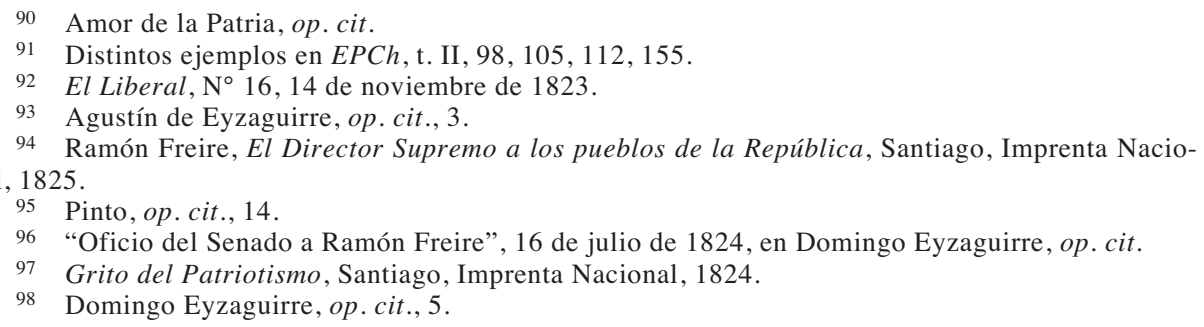


remedio parece se halla contagiado de la epidemia de una parte del pueblo insolentado"99. Y ante la última sublevación de la ciudad de Concepción, en 1829, el gobierno central determinaba "evitar los terrores de la anarquía convocando nuevamente a los pueblos, para rehacer las elecciones"100.

Una vez instalado firmemente el poder del Estado bajo la forma del centralismo conservador, el concepto de pueblo será tomado desde una perspectiva que mezclaba tanto el énfasis en el orden y el peso de la tradición de obediencia (entendida como un valor), como los deberes de corte regenerador dirigidos por el gobierno, proclives a la educación, la represión de la criminalidad y la prevención de las mortales epidemias, taras sociales que promovían, en la "clase inferior", un "olvido de sí mismos" remediable tan solo con el viejo binomio policía/caridad ${ }^{101}$. De esa forma, el gobierno se volvía a conceptuar como "verdadero padre del pueblo", que junto a sus representantes "no cesan de darle muestras de amor, de ilustración y de patriotismo"102. En contrapunto, a partir de la década de 1840 se harán frecuentes las críticas opositoras a las prácticas autoritarias del gobierno, preguntándose cómo "un pueblo privado de su libertad está en estado de elegir", considerando además que las elecciones constituían "el único acto de soberanía que se ha reservado el pueblo, y del cual depende principalmente su felicidad"103. Similar juicio se emitía en relación a los pueblos que, siempre de acuerdo con los liberales, habían resistido "los múltiples esfuerzos de la autoridad por embrutecer a los pueblos, y hacerlos familiares con la opresión y tiranía”, manifestando, a pesar del "vergonzoso papel que les hacían representar en las farsas electorales", una actitud de honor y la defensa de sus intereses específicos ${ }^{104}$.

De esa forma, la última parte del periodo aquí abarcado estuvo dominada por la reconceptualización del pueblo y los pueblos como agentes que, esta vez sometidos a un despotismo republicano, poseían la facultad de la violencia política, en tanto "una explosión general, que en tal caso sería inevitable sobre sitios, ejércitos y violencias, ostentaría el poder nacional, y mostraría que nunca por largo tiempo pueden los gobiernos insultar a las naciones"105. Con un recurso conceptual emanado de la observación del conjunto del proceso republicano, la misma fuente recordaba a sus lectores que "el fijar en un pueblo nuevo un orden constitucional, siempre fue empresa peligrosa", dada la incidencia de facciones opuestas que se

99 Freire, op. cit., 5.

100 El Lucero o Almanak chileno para el año de 1830: vigésimo primero de nuestra Regeneración política, e Independencia Nacional; y tercero de Nuestra Constitución, Valparaíso, Imprenta del Mercurio de Valparaíso, 1830, 19.

101 Ramón Luis Irarrázaval, Memoria que el Ministro del despacho en el departamento del Interior presenta al Congreso Nacional de 1839, Santiago, Imprenta de La Opinión, 1843, 25.

102 Ramón Luis Irarrázaval, Memoria que el Ministro del despacho en el departamento del Interior presenta al Congreso Nacional de 1843, Santiago, Imprenta de La Opinión, 1843, 6-8.

103 Los Amantes de la Libertad, Día primero de junio de 1840, Santiago, Imprenta de Colocolo, 1840 .

104 Algunas observaciones arregladas a los principios y a la opinión de los pueblos de Chile, Valparaíso, Imprenta Liberal, 1841, 2.

105 Ibid., 10. 
desarrollan en el seno de este ${ }^{106}$. Ya avanzada la década de 1840 , la existencia de estas facciones se hacía indesmentible, y desde el gobierno conservador se aplicaba la lógica de la sedición organizada y minúscula para explicarlas, dado que

\begin{abstract}
"algunos descontentos, que nunca faltan aún en los pueblos más adelantados, se aprovecharon de la excitación que en los ánimos producen las épocas de elecciones, para promover las revueltas y la anarquía [...] buscaron sus prosélitos en las ínfimas clases de la sociedad, tan fáciles a la seducción, y no perdonando medio alguno por insano que fuese, trataron de indisponerlas, e inspirarles odio contra las clases acomodadas"107.
\end{abstract}

Respuesta a este tipo de argumentos puede encontrarse en la obra del escritor y filósofo liberal Francisco Bilbao, quien en el prólogo de su traducción a la obra de F. Lammenais, De la esclavitud moderna, volverá a revisar, desde un prisma fuertemente influido por las teorías políticas liberales de la Europa de mediados del siglo XIX, los distintos tópicos conceptuales que vinculaban estrechamente al pueblo con la soberanía de las naciones, en tanto desde sus primeras páginas reconoce que es justamente el pueblo el soberano. Y ello a pesar de que, observado con atención, el pueblo no mostraba sino "vicios, superstición, fanatismo e intolerancia”, además de ignorancia, miseria, expoliación laboral y una criminalidad percibida como en ascenso. En pocas palabras, "el hombre del pueblo no conoce su deber social y su derecho, vende su voto y no tiene ni toma interés en los negocios públicos", razón que le impide ejercer su soberanía efectiva -siempre atada a la ilustración de sus miembros, cuyos principios el autor identifica explícitamente con la libertad, la fraternidad y la "armonía de todos"- y con ella liberarse de las lacras que lo acosaban por responsabilidad del gobierno conservador. La respuesta de Bilbao al “cómo obrar sobre el pueblo?” es sintetizada en el concepto de reforma, inspirado en el doble principio de "rehabilitarlo, hacerlo susceptible de que marche acorde y sea capaz de llevar una bandera" y "obrar con él sobre lo que se oponga a su desarrollo y su libertad". De esa forma, el pueblo de Bilbao -ese "hombre del pueblo, bien seas el artesano industrioso, o el peón gañán asalariado, o el campesino despotizado por el hacendado"- toma la forma de la "unión y fuerza del Océano", al enfrentar las trabas a su propia libertad por medio de la ilustración de la reforma ${ }^{108}$. De modo asimilable, Santiago Arcos, compañero de Bilbao y como él obligado al destierro tras el alzamiento de la Sociedad de la Igualdad en 1851, explicaba desde la prisión que el gobierno que los había derrotado quería "conservar al país en el estado en que está porque el peón trabaja por real y medio y solo exige agua y porotos para vivir, porque pueden prestar su plata al $12 \%$ y porque pueden castigar al pobre si se desmanda" ${ }^{109}$.

106 Ibid., 20 .

107 Manuel Montt, Memoria que el Ministro del despacho en el departamento del Interior presenta al Congreso Nacional, Santiago, Imprenta de La Opinión, 1846, 1-2.

108 Francisco Bilbao, prefacio a la edición chilena de F. Lammenais, De la esclavitud moderna, Santiago, Imprenta Liberal, 1843, II-VI.

109 Santiago Arcos, "Carta a Francisco Bilbao" [1852], en Santiago Arcos, Carta a Francisco Bilbao y otros escritos, Cristián Gazmuri (ed.), Santiago, Editorial Universitaria, 1989. 
El hecho de que los autores recién citados hagan una descripción de las formas de trabajo ejercido por los hombres del pueblo, como un argumento de su reconocimiento como interlocutores, plantea el movimiento semántico desde el concepto de pueblo como unidad comprensiva de conjuntos de población no caracterizados por su pertenencia de clase, hacia su identificación limitada a la esfera de los pobres y trabajadores. Pocos años más tarde, otra publicación hará referencia a que visitando al pueblo podían observarse tanto "escenas escandalosas de inmoralidad y corrupción”, como "artesanos honrados que leían con complacencia i entusiasmo los periódicos en que se les deslindaban sus derechos". El mismo gobierno en la Memoria del Ministerio del Interior de 1847, suponía al pueblo satisfecho "con la vida tranquilamente laboriosa a la sombra de una moderada libertad" y el mejoramiento de "la condición de las masas y su bienestar material", como el mejor antídoto ante "las quimeras vanas, que se sueñan en el febril desasosiego de las revueltas civiles"110. A este cambio de significación se le asignó el imperativo de la reforma, lo cual implicó, en un ejercicio de recurrencia conceptual significativo, la posibilidad de la restauración, de la regeneración, tal y como se podía notar en el periodo previo a la emancipación o en medio de la guerra, cuando se hacía indispensable la rebelión y la fuerza en contra del régimen ilegítimo. Así, acusando al gobierno de intervención electoral y distorsión criminal de la soberanía del pueblo, un comentarista liberal desde Concepción pretendía

"patentizar que la voluntad del pueblo no ha sido libre, puesto que el poder se ha valido de la fuerza i de las amenazas en la elección que se ha hecho, deduciendo como consecuencia indispensable que si el pueblo no puede obrar con voluntad libre al ejercer el más augusto de sus derechos en un gobierno representativo este pueblo, o es muy nulo, muy ignorante, muy estúpido y merece que lo enyuguen, que lo encadenen, que lo despotizen, o si por el contrario tiene conocimiento de sus derechos y sabe cuánto vale el ser libre, el día de la restauración vendrá"111.

Para otros, y utilizando el recurso de apelación al pueblo desde la experiencia libertadora de las guerras de independencia, su impotencia para el ejercicio de los derechos conseguidos en esas gestas obligaba a expresar:

“os gobierna una política basada sobre corruptores principios. ¿Mecidos, empujados, arrastrados os dejáis como ciegos conducir por torcidos senderos? ¿Cerráis vuestros ojos a los peligros que os cercan, a los testimonios constantes de vuestro abatimiento, ahogáis los impulsos laudables de vuestra dignidad humillada, los arranques del patriotismo, los avisos luminosos de la razón, preferiréis divertiros, holgaros en vuestra propia miseria, antes de escuchar los consejos del valor, y sobrellevar las fatigas indispensables a toda noble resolución? ¡Día llegará que sea expuesta en toda su claridad la

110 Memoria del Ministerio del Interior, Santiago, Imprenta El Progreso, 1847, 6.

111 José Antonio Alemparte, Despedida del Eco Nacional. Esposición de los abusos, tropelías e infracciones de lei que han anulado de hecho la elección de diputados i electores de senadores, practicada en la mayor parte de los departamentos de esta provincia; $i$ las consecuencias de un proceder tan arbitrario, Concepción, Imprenta de la Libertad, 1846, 10. 
villanía de esta época; y los chilenos que la reconocerán confundidos, querrán borrarlas de las páginas de su historia! Nosotros, educados en la oscuridad del coloniaje, tenemos disculpa de nuestros vicios, en la odiosa depredación de los tiranos: con todo nos sobró decisión y denuedo para romper nuestras cadenas; pero vosotros viciosos, corrompidos, después de tan heroicos ejemplos, después de haberos amamantado con la leche de la libertad, con más experiencia y luces que nosotros, es el colmo de la ignominia, y más nos habría valido ahorrarnos tan costosos esfuerzos"112.

Ya en 1850, otro autor acusaba también la impasibilidad del pueblo ante los abusos electorales del gobierno, cuestionando la capacidad de este de hacer efectivos sus deberes: “¡Pueblo charlatán! Hasta cuándo te dejarás burlar y pisotear como vil esclavo a quien su altivo señor halaga y azota alternativamente! No tendrás vista para ver tu miseria, dignidad para repeler los agravios, valor para vengar tu degradación!"113.

De esa forma, la negación y el límite de la soberanía del pueblo están dados por la ignorancia de sus derechos y por ello su incapacidad de ejercerlos. Esta incapacidad no se explicaba solo por la ignorancia de los pobres, sino también por los abusos electorales del gobierno, que dejaban "abatido el pueblo, penetrado de su flaqueza, renegando de sus derechos y abandonando el campo electoral como un teatro donde lo entregan a la mofa cruel, a la humillación y al vilipendio"114. Así, para los partidarios del liberalismo el principal responsable de esta situación era el gobierno conservador (definido como un nuevo despotismo que con una falsa libertad "engaña al pueblo, haciéndole creer que posee un bien, que apenas alcanza a divisar"), para quien el inmovilismo popular representaba una ventaja. Y por ello, "la oposición, rechazada del gobierno, ha ligado su causa más íntimamente con la del pueblo, cifra su fuerza en el favor de este y espera su triunfo del ascendente de la opinión"115. Más aún, y en caso de no ser escuchados e incorporados al gobierno, esa misma oposición liberal advertía que se acercaba el momento en que, producto de los abusos y tropelías,

\begin{abstract}
"los hombres que hasta ahora se han esforzado en contener la corriente revolucionaria, la dejarán seguir su curso; entonces la ignorancia del pueblo, lejos de ser útil al gabinete, lejos de favorecer sus intrigas, contribuirá a formar una masa muy compacta que, viendo solo los efectos palpables del despotismo y no alcanzando a ver los horrores de la anarquía, se alistará en las filas de esta y cooperará con todas sus fuerzas a destruir el despotismo".
\end{abstract}

Luego de un "día borrascoso y terrible [...] veremos nacer un porvenir risueño para Chile", regenerado del despotismo ${ }^{116}$. La percepción de que ese "día borrascoso" estaba cerca será comentario frecuente en el pensamiento liberal cercano a la mitad del siglo XIX, periodo en el que efectivamente se desarrollaron asonadas

\footnotetext{
112 Un patriota viejo, El 18 de septiembre en 1846, Santiago, Imprenta de La Oposición, 1846, 10.

113 Francisco Marín, El último acento de un chileno, Santiago, Imprenta Chilena, 1850, 6.

114 Un patriota viejo, op. cit.

115 Marín,op. cit., 21.

116 Alemparte, op. cit., 47-48
} 
revolucionarias y alzamientos locales como manifestación del descontento frente al orden conservador. Antes de estos acontecimientos, un autor indicaba: "Cuando un volcán cierra repentinamente su cráter y permanece por mucho tiempo sin humear ni arrojar lavas, son muy temibles los efectos de su erupción: parece que los días de calma se hubiesen ocupado en reunir elementos para aterrar al mundo con sus estragos"117.

\section{REGENERACIÓN, REVUELTA Y RESIGNACIÓN: EL PUEBLO Y SU CIUDADANÍA IMPOSIBLE EN EL PENSAMIENTO DE SANTIAGO ARCOS Y FRANCISCO BILBAO}

A poco de fracasados los motines militares e intentos de sublevación que marcaron los primeros meses del año 1851, el mismo Bilbao declaraba, en una misiva a su amigo Santiago Arcos, que "la revolución se perdió porque no fue revolución"118. En su respuesta Arcos, prisionero en la cárcel de Santiago, reconocía por su parte: "nuestro pensamiento fue sofocado por la precipitación para llegar al mando y por la poca fe en la República de los jefes del partido al cual pertenecíamos entonces" ${ }^{119}$. A pesar de las intenciones, de la presteza de su ideario liberal, del logro de haber movilizado a tropas y artesanos y de haber vinculado a una parte del pueblo con las esferas de la alta política -de corte conspirativo y especular-, la resaca del fracaso y la derrota se deja ver en los escritos de ambos personajes. Nacidos Arcos y Bilbao pocos años después de finalizadas las guerras de Independencia en Chile, y aunque sus destinos prontamente se alejaron geográficamente -este crece en Chile, aquel pasa su infancia y juventud en Francia-, el influjo de las expectativas políticas puestas en las luchas independentistas será, a lo largo de sus escritos, evidente. La revolución libertadora, de la que no tomaron parte y cuyas historias debieron de recorrer sus imaginaciones infantiles, se convirtió para ambos en el paso histórico que su propio país no había logrado proyectar hacia el mundo social en su totali$\operatorname{dad}^{120}$. El fracaso de este proyecto independentista -teñido del ideario liberal que

\footnotetext{
117 Ibid., 57.

118 Francisco Bilbao, "Carta a Santiago Arcos" [1851], en Francisco Bilbao, La revolución en Chile y los mensajes del proscrito, Lima, Imprenta del Comercio, 1853, 70.

119 Arcos, "Carta a Francisco Bilbao", op. cit., 103. La numeración de las páginas de esta carta sigue a la establecida en Arcos, Carta a Francisco Bilbao y otros escritos, op . cit.

120 Como concepto aglutinador de diversas acciones e idearios políticos, la revolución opera con fuerza en el pensamiento político de Bilbao. Ello al menos desde dos perspectivas: la necesidad histórica de darle continuidad al proceso independentista -calificado de revolucionario-; y la legitimidad política que otorgaría la misma revolución. Sobre la primera idea es indicativa la siguiente cita de Sociabilidad Chilena: "La inmortalidad de un gobierno en la historia de su pueblo, consiste en comprender la idea culminante que el siglo le presenta para su realización y realizarla. Entre nosotros la idea culminante como herederos de la revolución es completarla. Completar la revolución es apoyar la democracia en el espíritu y la tierra, en la educación y la propiedad. Esta obra es la destrucción de la síntesis autoritaria del pasado y la sustitución de los principios que la filosofía reconoce con el sello de la inmortalidad. Esta obra importa una revolución”. Francisco Bilbao, Sociabilidad chilena, edición y compilación de José Alberto Bravo, Santiago, Editorial Cuarto Propio, 2007, 171. Sobre la segunda idea -referida al tópico maquiavélico de la legitimidad revolucionaria-, pocas páginas antes el mismo Bilbao expresaba: "O los gobiernos han salido de las entrañas de la revolución y entonces es legítima su existencia, o no, y entonces son desconocidos como autoridades del pueblo revolucionario". Ibid., 21. En similar sentido se
} 
sustentaron- se hizo aún más evidente al momento de experimentar situaciones históricas de convulsión en otras latitudes. Arcos vivió la monarquía de Julio y su paulatina descomposición; Bilbao fue desterrado luego de la publicación de Sociabilidad Chilena en 1844, y su exilio lo llevó a Francia, a la misma Francia que se debatía en las barricadas de 1848. En ese contexto se conocen, y junto a su formación académica -al alero de personajes como Quinet, Michelet y Lamennais- debatieron la situación política, cultural y social de su país de origen. Como bohemios estudiantes, como románticos e insurrectos, las calles de París, así como fugaces viajes a Inglaterra, España, Italia y California, los impregnaron, a lo largo de sus vidas, de una cultura cosmopolita, de un acercamiento vivencial a los grandes procesos del siglo, a los debates político-filosóficos, a las luchas de muchos pueblos, de pueblos pobres, por la igualdad y la dignidad de derechos.

Retornados a Chile -Arcos en 1847, Bilbao en 1850- su amistad se tradujo en la organización de una instancia de discusión y participación política hasta entonces inédita en el país: con el modelo de los clubes de artesanos y obreros franceses en la mente, fundaron en 1850 la Sociedad de la Igualdad, primera organización que hizo coincidir a artesanos y políticos liberales en la acción política, y que, tras una corta y agitada vida, sucumbió bajo la represión del gobierno conservador, no sin antes haber protagonizado una serie de motines y alzamientos en Santiago, San Felipe y La Serena. Tras los hechos, de breve duración pero largo impacto, ambos conocen el exilio, y Arcos, la cárcel. Esta nueva diáspora los llevará, ya separados en sus caminos, a volver a Europa, y más aún, a involucrarse en asuntos americanos. Argentina y Perú fueron sus destinos de paso. Arcos pasa de Chile al Perú y desde ahí a California, recorrido tras el cual volverá clandestinamente a Valparaíso, donde fue encarcelado y posteriormente exilado a Mendoza. En 1855 se trasladó a Buenos Aires, en donde cultivó la polémica política al lado de hombres de la talla de Mitre, Sarmiento y Vicente López. Instalado en una isla del río de La Plata, tomó claro partido por el centralismo bonaerense, obteniendo un rango militar y participando en las guerras contra los federalistas, en cuya trinchera peleaba su antaño amigo, Francisco Bilbao. A mediados de la década de 1860 retornó a París, desde donde se trasladó a España e Italia. En España participó activamente en política, llegando a postularse por el Partido Liberal para las elecciones a Cortes Constituyentes de 1869. En Nápoles, dos años después, lo encontró Benjamín Vicuña Mackenna, ya avejentado y, de acuerdo al futuro intendente de Santiago, convertido en un conservador. Enfermo de cáncer, retorna a París, lugar en el que, desde uno de los puentes del Sena, se suicida "como un poeta sin pan, en medio de la gran tristeza del atardecer" 121 .

expresó también Arcos cuando, a pesar de la derrota, siguió reconociendo en la revolución el elemento proveedor de legitimidad para cualquier gobierno: "Si llegásemos al poder, sea por un motín miliar, sea por una fuerte asonada popular o por ambas cosas reunidas, lo que no es imposible, seríamos, como revolucionarios, Gobierno nuevo, es decir, todopoderoso. Si algún Gobierno establecido, sean cuales fueren sus antecedentes, adoptase nuestras ideas, sería, por el hecho de adoptarlas, Gobierno revolucionario, nuevo, todopoderoso". Arcos, "Carta a Francisco Bilbao", op. cit., 93.

121 "El suicidio de Santiago Arcos", en Le Figaro, 25 de septiembre de 1874. Esta nota necrológica, así como los datos biográficos y los textos de Arcos que se citan han sido extraídos de Arcos, Carta a Francisco Bilbao y otros escritos, op. cit. 
Francisco Bilbao, por su parte, que ya había conocido el destierro con motivo de la publicación, censura y quema pública de Sociabilidad Chilena, tras los sucesos de 1851 huye, vestido de sacerdote, a Lima, ciudad desde la cual redactará su conocida carta a Santiago Arcos, que este responderá desde la prisión. En el Perú, Bilbao, junto a sus hermanos Manuel y Luis, rápidamente se involucró en política, organizando grupos de jóvenes liberales a favor de la abolición de la esclavitud y la primacía de la razón por sobre el influjo de la opinión eclesiástica. Esta disputa contra el catolicismo, tal y como había sucedido en Chile en 1844, le costó la persecución y la censura, por lo que debió asilarse en la embajada de Francia por tres meses. La persecución que concluyó con su relegación a Guayaquil, lo motivó a escribir Revolución de la Honradez, texto rápidamente multiplicado por los partidarios de Castilla en contra del presidente Echenique. Su adición al proyecto político castillista no se detuvo ahí, participando Francisco junto a sus hermanos en la toma de Lima por parte del caudillo. Sin embargo, la paz no anidaría en su acción, por lo que, tras insistir en sus polémicas anticlericales, sus amigos logran enviarlo a París, en 1854. Tres años después vuelve a América, se instala en Buenos Aires y funda la Revista del Nuevo Mundo, tribuna desde la cual apoyará a Urquiza y el proyecto federal en Argentina. Desde esta ciudad continuó escribiendo y discutiendo contra sus más avezados enemigos: el clero, el conservadurismo y la intervención extranjera. Ante la agresión francesa a México publica La América en peligro, en 1862. Ya enfermo de tuberculosis, en 1864, da a las prensas su última obra, verdadero tratado de hegelianismo filosófico, El Evangelio Americano, revisión especulativa de la historia americana y de las posibilidades humanizadoras de la revolución liberal y democrática. El 19 de febrero de 1865 muere, tras 42 años de intensa experiencia ${ }^{122}$.

En el centro de la conceptualización del pueblo que tanto Arcos como Bilbao realizan, radica, sin embrago, una firme creencia en la exclusión efectiva del pueblo de los deberes de la ciudadanía. La práctica política de distorsión de la soberanía que denunciaban en el gobierno conservador terminaba por convencerlos de la incompetencia real del bajo pueblo para el ejercicio de sus derechos, por lo que estos debían de otorgarse solo tras el cedazo de la propiedad. Antes que en la colectividad -el pueblo- la razón política habita en los ciudadanos, en tanto que el liberalismo doctrinal del que bebe Arcos instala su principal fortaleza en la defensa y promoción de los derechos individuales, ajenos a cualquier clase de privilegio o desigualdad. El mismo Arcos lo expresaba con claridad en La Contribución y la Recaudación, escrito en el marco del que, aunque de temática primordialmente económica, indicaba:

"La democracia es el poder en manos de todos. Bajo la democracia no debe haber ni individuo ni clase privilegiada, ni debe el rico oprimir al pobre, ni el pobre oprimir al rico. El poder debe hacerse sentir lo menos posible, es decir, dejar a cada individuo la mayor suma posible de libertad individual. El poder debe cuidar de que el individuo no

122 La información biográfica reseñada ha sido adaptada de Francisco Bilbao, El Evangelio Americano, Alejandro Witker (ed.), Caracas, Biblioteca Ayacucho, 1988. 
pueda hacer daño a la masa, ni a una fracción, ni a otro individuo, así como debe asegurar a cada individuo sus derechos, y recordar a las masas cuáles son sus deberes para con cada uno de los miembros que componen esa masa"123.

Por lo anterior, no es extraño que se insista en la centralidad del derecho de propiedad, como matriz de origen de cualquier actitud ciudadana y libre. El hombre libre y justo ante la ley es aquel que hace uso efectivo de su derecho de propiedad, aquel que posee y es respetuoso de la propiedad de los otros. Trabajo, riqueza, honor y propiedad se convierten en los antecedentes puntuales de un gobierno de ciudadanos, y más aún, de la constitución de ciudadanos respetados y respetables en su posición con respecto al gobierno. Un gobierno de propietarios es un gobierno civil, progresista y dedicado al Bien Común. Una sociedad de propietarios es, más aún, una sociedad democrática, justa y que avanza hacia la felicidad:

"Solo en la democracia el derecho de propiedad es y puede ser un verdadero derecho. Así vemos que las democracias, o los países cuyas instituciones se acercan más a las instituciones democráticas, son las que presentan una sociedad más adelantada, más feliz, más fuerte. Debemos, pues, reconocer el derecho de propiedad como el primero, el más precioso de los derechos del hombre, y la propiedad como el complemento necesario al hombre" 124 .

El conflicto entre este liberalismo individualista y propietario y las condiciones y medidas de redistribución de la riqueza, tan necesarias en un país de profundas y evidentes desigualdades como el Chile del siglo XIX, no tardó en aparecer, marcando un momentáneo punto de inflexión en el ideario político-social de Santiago Arcos. Este punto de inflexión -el más visitado y comentado por la historiografía, y en particular aquella de inspiración marxista- tomó cuerpo en la respuesta que Arcos escribe desde prisión a Bilbao, en donde indicaba, a modo de programa revolucionario, la urgencia y justicia de la redistribución:

"Es necesario quitar sus tierras a los ricos y distribuirlas entre los pobres.

Es necesario quitar sus ganados a los ricos para distribuirlos entre los pobres.

Es necesario quitar sus aperos de labranza a los ricos para distribuirlos entre los pobres.

Es necesario distribuir al país en suertes de labranza y pastoreo"125.

123 "La contribución y la recaudación", en Arcos, Carta a Francisco Bilbao y otros escritos, op. cit., 126.

124 Ibid., 128. Algunos párrafos antes, en el mismo "La Contribución y la Recaudación”, Arcos comentaba: "El respeto al derecho de propiedad, la libertad más amplia posible deja a cada ciudadano para disponer como guste de lo que posee, es el aliciente mayor que puede tener el hombre para producir, para rodearse de comodidades materiales, que son la base indispensable para que el hombre pueda emprender trabajos de un orden más elevado - para que el hombre pueda cultivar su inteligencia". Ibid., 127. Del mismo modo, y ya en 1868, en su escrito a los electores españoles para las Cortes Constituyentes, indicaría: "El trabajador, que siempre que quiere, puede ahorrar la centésima parte de su jornal, tiene una posición social tan acreedora a nuestros respetos, como el capitalista diez veces millonario que vive con previsión, sin gastar más de lo que tiene; uno y otro, aunque con distintas condiciones, viven en la completa posesión de su libertad individual, y basta interrogar nuestra conciencia para comprender que, socialmente hablando, el hombre de bien pobre, es igual al hombre de bien rico". Ibid., 176.

125 Ibid., 107. 
¿Es esto socialismo? Para algunos autores sin duda, en tanto que se propone al Estado como agente de expropiación y redistribución de la riqueza nacional. Más aún, se emparentan estas declaraciones con el ideario socialista en tanto que la diferenciación y oposición entre ricos y pobres se expresa con meridiana claridad. Sin embargo, consideramos que la intención de Arcos se limita tan solo a la redistribución, con el fin no de socializar los medios de producción -como propondría cualquier socialista cabal-, sino de mutar a los campesinos y pobres en propietarios, hacerlos ciudadanos a punta de responsabilidades y bienes, vinculándolos a la ciudadanía a partir de su esfuerzo e intereses individuales antes que sociales o comunitarios. Del mismo modo, cuando Arcos habla de ricos y pobres no lo hace en tanto clases sociales antagónicas y dueñas de proyectos político-sociales opuestos y en permanente conflicto, sino que desde la lógica de las castas, de los grupos estancos, imposibles de mixturar, que solo pueden ser igualados en base de la utilización de sus derechos, no importando por ello su posición en relación al sistema productivo o la magnitud de sus riquezas. En el fondo, para Arcos pobres y ricos son iguales en dignidad y derecho, siempre y cuando respeten las normas esenciales del juego republicano. El Estado expropiador y redistribuidor es un accidente histórico que debe tener la virtud de la brevedad y la justicia, no el papel centralizador y planificador que le asignaría el socialismo científico ${ }^{126}$.

Consecuentes con lo anterior, para Bilbao y Arcos la ruta hacia el progreso estaba definida por la adscripción a la libertad de comercio y de circulación de capitales, el free trade y libre échange son, en sus propias palabras, las únicas formas de consolidar la riqueza de una nación y la prosperidad y compromiso republicano de sus ciudadanos. Por ello, desde sus primeros escritos, Bilbao crítica al gobierno chileno por la mantención de formas económicas añejas y atrasadas, inútiles para el desarrollo económico del país:

"En la esfera del comercio y de la industria existen todavía los restos de la síntesis prohibitiva y privilegiadora. El Estanco existe, la moneda se quita de la circulación para formar un banco. Quitar de la circulación la moneda es empantanar los caminos. Guardarlo para juntarlo es perder el empleo de los capitales, es perder" 127.

126 En lo general, coincidente con este análisis de lo inapropiado de la caracterización de socialista en el ideario de Arcos es Cristián Gazmuri en su artículo "El pensamiento político y social de Santiago Arcos", Historia 21, Santiago, 1986. Agréguese a todo lo anterior el hecho de que en el programa de Arcos se postula un proceso de conversión de los sectores populares, fundamentalmente en campesinos, y no así en obreros industriales, artesanos o técnicos. Es decir, la misma existencia y fortalecimiento de una clase trabajadora no campesina no es relevante para Arcos, como sí lo será para todo el pensamiento socialista contemporáneo y posterior. Es más, su oposición y rechazo a las tesis de los socialistas utópicos es clara en cuanto expresa, en el marco de "La Contribución y la Recaudación" que "no vamos a apelar a las terribles teorías de Luis Blanc, del espantoso Proudhon, a las locuras de Fourier" (133). Por otro lado, en términos de aire maltusiano se refiere, en la misma obra, al problema del desempleo: "pero cuando el número de trabajadores es mayor que en todos los ramos del trabajo ¿qué hay que hacer? La naturaleza remedia el mal, por los terribles medios que conocemos: la emigración, la cárcel, las epidemias. En todo estudio económico se debe tener presente esta triste verdad" (134).

127 Bilbao, Sociabilidad Chilena, op . cit., 172. Del mismo modo, en "La Contribución y la Recaudación”, el prólogo de Bartolomé Mitre indica que uno de los objetivos de Arcos al escribir dicha obra es "hacer desaparecer todas las trabas que impiden desarrollarse libremente al comercio, la industria, al crédito y a los capitales en circulación" (117). 
De ese modo, la salida a la opresión conservadora y al gobierno de las excepciones constitucionales radicaba tanto en la apertura económica de Chile a los mercados extranjeros, como en la formación del pueblo, la construcción de una ciudadanía política moderna y transformadora. Los albures de esta transformación representan un punto de juicio de gran interés, en tanto el conflicto entre la realidad que Bilbao y Arcos denunciaban y la altura de sus proyectos puede ser visto como insoslayable. Y eso en gran medida por la visión que sostenían con respecto a las grandes mayorías del país. Con la acidez de sus plumas y lo excepcional de sus propias vidas y formación, las palabras que ambos reservan al pueblo de Chile son siempre degradantes y desesperanzadas. Para Francisco Bilbao la sociedad chilena colonial podía ser descrita como una cadena infamante de servidumbres: "esclavos del gobernador; el gobernador del rey y el rey del Papa. El hombre no comprende nada más allá de este círculo. Dios lo quiso, 'hágase su voluntad' es el tapaboca a la interrogación de la libertad. Luego no hay ciudadano ni pueblo. Hay esclavos y rebaño" 128 .

Pueblo de esclavos, de jornaleros sin derecho ni poder, de sombras de ciudadanos, de rebaños que dóciles se conducen desde la cuna triste a la sepultura fatigada. Como mayorías sin destino ni nombre, los pobres de Chile ven desfilar el mundo como una tragedia de la que nada tiene que decir:

"He aquí el grande espectáculo; el pueblo, la imagen del infinito, si puede haber imagen de él. Helo aquí que va y viene sosegado, sin la conciencia del poder de sus entrañas. Helo aquí que puebla las cárceles, que abastece el cadalso, que gime en los carros, que enriquece al propietario, que sobrelleva el insulto; helo aquí trabajando para el cura, para el Estado y para el rico; helo aquí recibiendo la sucesión de los días con la frente de mármol y sin reflejar en sus ojos la divinidad de la Luz. La noche misteriosa lo recibe fatigado y le protege un descanso animal. El día se levanta y el sol de Chile luminoso sirve tan solo para secar el sudor de su angustiada frente" ${ }^{129}$.

La condición del pueblo era el principal obstáculo de cualquier intento de flexibilización de las formas de participación política. Ese pueblo, presente en la historia nacional como un espectador foráneo, era el que llenaba las calles y los campos, el que laboraba en sus ranchos miserables o en las ciudades, de a poco atiborradas por su presencia desgreñada. Peones y labradores, gañanes e inquilinos de sierva condición, los paisajes de Chile le han servido de escenografía a procesos que no han ayudado ni a alimentar sus bocas ni a cultivar su barbarie, en tanto

128 Bilbao, Sociabilidad Chilena, op. cit., 159. Pocas páginas más allá, describiendo la etapa posterior a la Independencia, sostenía: "Pero el pueblo, que había abrazado la causa nueva con toda la pureza de la inspiración, con todo el calor del entusiasmo verdadero; el pueblo que solo había sentido la exaltación política, la conquista del derecho de ciudad; el pueblo, no vio en la libertad política sino un hecho solitario, separado de las demás cuestiones que la reflexión había derribado y el pueblo quedo antiguo" (164).

129 Ibid., 173. Una perspectiva similar manifiesta Arcos, al indicar que "es necesario dar rango de hombres a los seres que hasta ahora sirven de instrumento de labranza a los dueños del suelo, de máquinas a los propietarios de minas". Arcos, "Carta a Francisco Bilbao", op . cit., 105. 


\begin{abstract}
"los pobres han sido soldados, milicianos nacionales, han votado como su patrón se los ha mandado, han labrado la tierra, han hecho acequias, han laboreado minas, han acarreado; han cultivado el país, han permanecido ganando real y medio; los han azotado, encepado cuando se han desmandado, pero en la República no han contado para nada. Han gozado de la gloriosa independencia tanto como los caballos que en Chacabuco y Maipú cargaron a las tropas del rey"130.
\end{abstract}

Por lo mismo, Bilbao, años después de la derrota, no hace sino fustigar a los chilenos en su Mensaje del proscrito, alejado de un país al cual pide tribuna, debate, conciencia de su propia esclavitud:

"I vosotros, ciudadanos de Chile, que presenciáis y respiráis esa atmósfera de muerte, que tarde o temprano os envolverá en su pestilencia, sin la protestación digna de los hombres, permanecéis atónitos i mudos, como si durmierais todos bajo la pira funeral de Loncomilla o bajo los escombros de la Serena. Muda está la prensa, muda la tribuna envilecida, anonadada la asociación, i sobre ese espectáculo de pavor i de silencio solo se ve a la oligarquía que se afianza, al papismo triunfante"131.

Nuevamente será Arcos quien buscará dar una respuesta a la interrogante de la apatía popular, de las distancias que median entre cada sujeto y su espacio de participación política, aquellas razones que hablan de la inexistencia de una formalización de la participación en elecciones que, a pesar de estar normadas constitucionalmente en marcos de voto masculino y de pequeños propietarios, se reducía a la práctica clientelística de los grandes señores, de la misma clase política que con el patronazgo y después con el cohecho obtenía su legitimidad:

“¿A esos nueve décimos de nuestra población para quienes la elección es un sainete de incomprensible tramoya, que entrega su calificación al patrón para que vote por él; para quienes no hay más autoridad que el capricho del subdelegado, más ley que el cepo donde lo meten de cabeza cuando se desmanda? No es por falta de inteligencia que el pobre no ha tomado parte de nuestras contiendas. No es porque sea incapaz de hacer la revolución. Se ha mostrado indiferente porque poco hubiese ganado con el triunfo de los pipiolos y nada perdía con la permanencia en el poder del partido pelucón"132.

A partir de este diagnóstico de desesperanza y barbarie popular, una vez fracasadas las asonadas liberales, la conceptualización que ocupa el espacio vacante de la entidad pueblo es la del temor a una revolución verdaderamente popular, el pavor al malestar indómito de los pobres, a su desmande, su ira y su violencia. Con la estrategia de la formación individualista y el adoctrinamiento político liberal se pretende alejar la posibilidad de que todo el orden republicano se desmorone, arrastrando en su debacle incluso a los mejor intencionados, a los "los hombres de

130 Arcos, "Carta a Francisco Bilbao", op. cit., 78-79.

131 Francisco Bilbao, "Mensaje del proscrito", en Francisco Bilbao, Obras Completas, Pedro Pablo Figueroa (ed.), Santiago, Imprenta El Correo, 1897, tomo III, 123.

132 Arcos, "Carta a Francisco Bilbao", 75-76. 
la ciudad, los descendientes legítimos del año 10; los ilustrados, los herejes si queréis" 133 , tal y como Bilbao y Arcos se definían. A pesar de utilizar a los pobres como un recurso amenazante ante las jerarquías conservadoras y la oligarquía -"si fuese preciso desencadenaré al elemento popular como una tempestad de la providencia para la purificación del país"134_, la misma amenaza buscaba ser conjurada. Se temía al pueblo como se temía a la catástrofe, en tanto en él se observaba lo bárbaro e incontrolable, lo primitivo, lo salvaje:

"El pueblo así, sin conciencia de su individualidad y de su posición social, animalizado con el trabajo del día y para el día, es el tropel y el torrente que amenaza con la voz del sedicioso, la destrucción de nuestro progreso. El peligro se ve, el abismo está palpable y no se le arroja nada para taparlo. ¿Queréis que se llene de cadáveres? ¿O creéis tener la fuerza suficiente para saltarlo? Error. La mano del plebeyo levantada, es la montaña que se despeña. Esa mano no se detiene sino cuando levanta las cenizas de lo que ha destruido" 135 .

Antecedente remoto de la mirada aterrada que la élite política chilena construyó en la última parte del siglo XIX e inicios del XX con respecto a las clases populares, el pensamiento político y social de Arcos y Bilbao, por el hecho de no desprenderse de su herencia doctrinal liberal, contenía dentro de sí una contradicción irrefutable: la imposición de la ciudadanía no podía realizarse sin la participación de los pobres en los marcos de funcionamiento de una república de ciudadanos; sin embargo, la edificación misma de esta república se realizó con el fantasma del temor al pueblo. Como corolario a la tormenta, el Ministerio del Interior advertía en la declaración de estado de sitio para Santiago y Aconcagüa en noviembre de 1850, y en alusión directa a la prensa liberal, que "la revolución, según aquella prensa, debía ser ejemplar y sangrienta y la cabeza de los magistrados y ciudadanos designados por sus propios nombres debían servir para aplacar al pueblo", el cual era incitado por

"clubs en donde se hacen predicaciones subversivas, se explotan la ignorancia y las malas pasiones de la clase poco acomodada. Los sufrimientos inseparables de los que viven del trabajo de sus manos, y aún los que tienen su origen en la condición misma del hombre se han exacerbado para perturbar los espíritus e incitar odios"136.

Desde su prisión, Santiago Arcos volvía a sostener, como primera necesidad de la derrotada Sociedad de la Igualdad, la entrega "a los pobres de un Catecismo que les haga conocer sus deberes y derechos, que les explique lo que ganarían con la revolución"137.

133 Bilbao, Sociabilidad Chilena, op. cit., 169.

134 Bilbao, "Carta a Santiago Arcos", op. cit., 62.

135 Bilbao, Sociabilidad Chilena, op. cit., 173.

136 Exposición hecha por el señor Ministro del Interior a su Excelencia el Presidente de la República, Santiago, Imprenta de Julio Belin, 1850.

137 Arcos, "Carta a Francisco Bilbao", op. cit. 
